
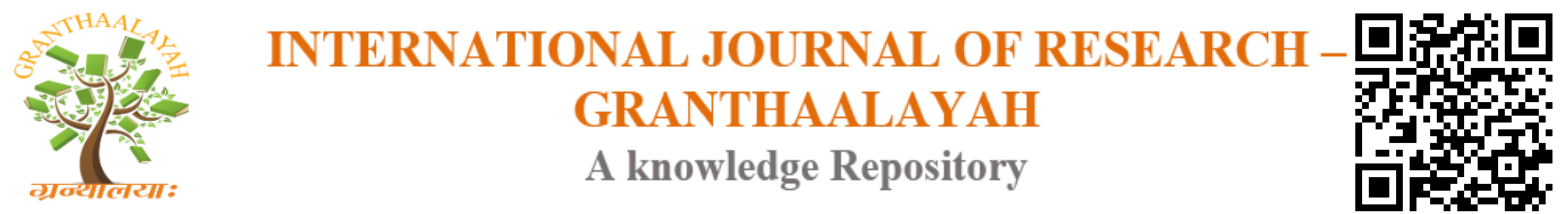

Science

\title{
MATHEMATICAL MODELING OF DIFFERENT DRYING METHODS OF DRIED OKRO SLICE
}

\author{
Olajire A. S. ${ }^{1}$, Tunde-Akintunde T. Y. ${ }^{1}$, Ogunlakin G. O. ${ }^{1}$, Adeyanju J. A. ${ }^{1}$ \\ ${ }^{1}$ Department of Food Science and Engineering, Ladoke Akintola University of Technology, \\ P.M.B. 4000, Ogbomoso, Oyo State, Nigeria
}

\begin{abstract}
Drying is an essential process that is used in preserving okro sample. This study investigates the modelling of dried okro slice using different drying methods. Freshly harvested okro fruits were cut transversely into slices $(0.5,1.5$ and $2.0 \mathrm{~cm})$ and dried using three different drying methods; sun, solar and oven at 40,45 and $50^{\circ} \mathrm{C}$. Drying of okro occurred in the falling rate period. Newton, Pabis, and Page and Henderson models were used to describe the drying of okro. An appropriate model was selected based on highest $\mathrm{R}^{2}$, least values of $\mathrm{X}^{2}$, Root Mean Square Error (RMSE) and Mean Biased Error (MBE). Page model described the drying behaviour of okro slice $0.5 \mathrm{~cm}$ satisfactorily having the highest $\mathrm{R}^{2}$ of 0.999 and lowest value of $\mathrm{X}^{2}\left(0.152 \times 10^{-8}\right)$, RMSE $\left(4.5 \times 10^{-}\right.$ ${ }^{6}$ ) and that of $\operatorname{MBE}\left(-3.089 \times 10^{-4}\right)$.
\end{abstract}

Keywords: Okro; Drying; Slice Thickness; Mathematical Modeling.

Cite This Article: Olajire A. S., Tunde-Akintunde T. Y., Ogunlakin G. O., and Adeyanju J. A. (2019). "MATHEMATICAL MODELING OF DIFFERENT DRYING METHODS OF DRIED OKRO SLICE." International Journal of Research - Granthaalayah, 7(3), 302-309. https://doi.org/10.29121/granthaalayah.v7.i3.2019.975.

\section{Introduction}

Okro (Abelmoschus esculentus L.) is an important vegetable crop that is grown in tropical and subtropical regions. It contains some essential nutrients which include protein, carbohydrate, fat, minerals and vitamins, and it's also high in antioxidant activity (Gemede et al., 2014). Okro, also known as okra, ladies fingers or gombo (Mana et al., 2012), contains high moisture content, this make it to deteriorate very fast. It therefore needs to be processed by reducing its moisture content so that it will be available throughout the year. Drying is one of the methods that can be used to reduce the moisture content present in okro to a level where microbial growth will be inhibited.

Drying involves simultaneous mass and heat transfer in high perishable crop such as fruit and vegetable to the level where growth of microorganism will be inhibited (Wankhade and Saplid, 2012). Traditional ways of drying (sun drying) is cheap but has some limitations in term of 
hygiene. This is because it exposes the food to dust, insect fly and even rain. Therefore there is need to change from traditional way of drying to modern ways of drying so that post-harvest losses will be reduced. Modelling is the most crucial aspect in drying technology because it is used to improve the existing drying system or in some cases in controlling the drying process (Darvishi et al., 2012). During modelling of agricultural products (fruit and vegetable), two type of models can be used which are; theoretical and empirical. Theoretical models are determined by theories and some laws which are so tedious to control and manage because of its complexity due to incorporation of different parameters (Maskan, 2002). Empirical models can be determined by simple mathematical equations based on experimental data obtained during laboratory experiment and the correct fit to experimental data can be obtained without considering the transport process involved (Pandey et al., 2015).

Several works conducted on the effect of drying condition on the modeling of fruits and vegetables have been published (Tunde-Akintunde et al., 2005; Tunde-Akintunde and Ajala, 2010; TaheriGarav and Alireza, 2015) Although the drying process and mathematical model of okro fruit using temperature of 40, 50 and $60{ }^{\circ} \mathrm{C}$ have been investigated by Famurewa and Olumofin (2015) in which Modified Page model was reported to be the best model, no study have been done and reported on slice thickness of $0.5,1.0$ and $2.0 \mathrm{~cm}$ thickness and comparison of three different drying methods: sun, solar and oven $\left(40,45\right.$ and $\left.50{ }^{\circ} \mathrm{C}\right)$. This study was therefore conducted to provide a comprehensive knowledge on the model that can satisfactorily describe okra drying data at different slices and different drying methods from three mathematical models (Newton, Page, and Henderson and Pabis).

\section{Materials and Methods}

\subsection{Material}

Freshly harvested okro was obtained from Teaching and Research Farm (Agronomy section) Ladoke Akintola University of Technology (LAUTECH), Ogbomoso, Oyo State. The fruit was deep green with elongated pointed edges, and had an approximate length of $7 \mathrm{~cm}$ and diameter of $1.8 \mathrm{~cm}$.

\subsection{Methods}

\section{Preparation and Drying Procedure of Okro Sample}

The okro was sorted to remove impurity and cut into slices of $0.5,1.5$ and $2.0 \mathrm{~cm}$ thickness. Sliced samples of $400 \mathrm{~g}$ were placed in drying trays of dimensions $42 \mathrm{~cm}$ by $27 \mathrm{~cm}$ and spread out in a thin layer. The sliced okro samples were dried using three drying methods namely; oven dry (at 40, 45 and $50{ }^{\circ} \mathrm{C}$ ), sun drying and solar drying. Readings were taken at regular intervals until constant weight was obtained after three consecutive readings.

\section{Oven Dryer}

An oven dryer (Gallenkamp BS oven, UK) with a heating element (rated $220-240 \mathrm{~V}$ and 1400 $1800 \mathrm{~W}$ ) situated at the Food Science and Engineering Laboratory in LAUTECH was used. Reading was taking at an interval of 30 min until constant weight was obtained. 


\section{Solar Dryer}

The sliced samples were placed inside the solar dryer which consist essentially of solar collector and drying chamber constructed with wood planks and transparent glass having a cross-sectional area of $16722.5 \mathrm{~cm} 2$ and placed directly in the sun. The duration of the drying was from 8 am -6 pm daily which represent the sunlight hours (Krutman, 1981). The samples were weighed every hour until three consecutive readings were constant.

\section{Sun Dryer}

The samples in the drying trays were placed directly under the sun. The duration of the drying was also between 8 am -6 pm daily (which represent the drying hour). The weights of the samples were measured hourly and the drying continued until three consecutive readings were constant.

\section{Drying Kinetics}

Moisture Content: The initial moisture content of okro before drying was determined using AOAC (2005). Since the determination of drying kinetics is based on the moisture content, the weight of okro during drying was converted to moisture content using Equation (1).

$$
M C=\frac{w_{i}-w_{d}}{w_{i}} \times 100
$$

Where, MC is the moisture content ( $\mathrm{g}$ water/g material), wi is the initial mass of the sample before drying $(\mathrm{g})$ and wd is the mass of the sample at time $\mathrm{t}(\mathrm{s})$.

Moisture Ratio: The moisture ratio during drying experiment was obtained by using Equation (2)

$$
M R=\frac{M-M e}{M i-M e}
$$

Where, MR is the dimensionless moisture ratio, $\mathrm{M}, \mathrm{Me}$ and $\mathrm{Mi}$ is the moisture content at any time, $\mathrm{t}$ (s), equilibrium moisture content and initial moisture content (g water/g material), respectively. However, the moisture ratio (MR) was simplified to $\mathrm{M} / \mathrm{Mi}$ instead of (M-Me)/(Mi-Me) because of the relative humidity of the drying air continuously fluctuated during open sun and solar drying processes (Menges and Ertekin, 2006). Hence, moisture ratio was calculated as:

$$
M R=\frac{M}{M_{i}}
$$

\section{Mathematical Modeling of Drying Curve}

In an attempt to describe the drying behaviour of okro under different drying conditions, three thin layer drying models were used (Table 1). The three equations were used in this study to describe the drying kinetic of okro during oven, sun and solar drying were namely Newton, Page, and Henderson and Pabis models. 
The Equations in Table 1 were fitted to the experimental data to select the best model that can be suitably used to predict the drying characteristics of okro slices using oven, sun and solar drying. The reduced chi square $(\chi 2)$, the mean bias error (MBE) and the root mean square error (RMSE) were used as the basis of selection. The equation with the highest value of R2 and lowest value of $\chi 2, \mathrm{MBE}$ and RMSE was chosen as the equation that best predicts the drying characteristics of okro. They were calculated using:

$$
X^{2}=\frac{\sum_{i=1}^{N}\left(M R_{i}-M R_{p r e d i}\right)^{2}}{N-Z}
$$

Table 1: Some Selected Thin Layer Drying Model

\begin{tabular}{|l|l|l|}
\hline Model & Name & Reference \\
\hline$M R=\exp (-k t)$ & Newton & Liu and Bakker-Arkema (1997) \\
\hline$M R=\exp \left(-k t^{n}\right)$ & Page & Zhang and Litchfield (1991) \\
\hline$M R=a \exp (-k t)$ & Henderson and Pubis & Mohamed et al. $(2005)$ \\
\hline
\end{tabular}

$$
\begin{aligned}
R M S E & =\left[\frac{1}{n} \sum_{i=1}^{N}\left(M R_{P R E D L}-M R_{E X P I}\right)^{2}\right]^{\frac{1}{2}} \\
M B E & =\frac{1}{n} \sum_{i=1}^{N}\left(M R_{P R E D I}-M R_{E X P I}\right)
\end{aligned}
$$

Where, MRexpi is the experimental moisture ratio, MRpredi is predicted moisture ratio $\mathrm{N}$ is the number of observation $\mathrm{n}$ is the number of constants in the equation. The regression was carried out using SPSS version 16.0 software.

\section{Validation of the Established Model}

The established model was validated by plotting the moisture ratio against time for the experimental and the predicted values from the established model for each experimental run (oven, sun and solar).

\section{Results and Discussion}

\section{Evaluation of The Drying Model of Okro Sample}

The models considered in this study were Newton, Page, and Henderson and Pabis models while the statistical parameters used for the comparison of the models were R2, $\chi 2$, RMSE and MBE. The model that best describes the thin layer drying characteristics of okro at different slice thicknesses was selected on the basis of having the highest R-square (R2) value above 0.9 and the lowest values of the $\chi 2$, RMSE and MBE. The values of these statistical parameters with different drying methods are as shown in Tables 2 and 3. The ranges of R2 for oven dried samples ranged from 0.879 to $0.996,0.892$ to 0.998 and 0.985 to 0.999 for all the slice thicknesses, dried at oven temperature of 40,45 and $50{ }^{\circ} \mathrm{C}$, respectively. 
The value of $\chi 2$ for oven dried samples ranged from $2.058 \times 10-5$ to $1.38 \times 10-2,0.156 \times 10-8$ to 0.0331 and $2.265 \times 10-6$ to $2.374 \times 10-3$ for all the slice thicknesses dried at oven temperature of 40, 45 and $50{ }^{\circ} \mathrm{C}$, respectively. The values of RMSE for oven dried samples ranged from 0.0114 $\mathrm{x} 10-3$ to $0.2382,0.2126 \times 10-4$ to 1.1757 and 0.053 to $0.0550 \times 10-4$ for all the slice thicknesses dried at oven temperature of 40,45 , and $50{ }^{\circ} \mathrm{C}$, respectively. Lastly, the range of values of MBE for oven dried samples ranged from $-1.830 \times 10-3$ to $0.0615,-0.0454$ to 0.0350 and -0.052 to 0.01462 for the same slice thickness dried at temperature of 40,45 and $50{ }^{\circ} \mathrm{C}$.

For sun dried samples the values of R2 ranged from 0.985 to $0.999, \chi 2$ from $8.327 \times 10-5$ to 0.13295; RMSE from 8.656 x 10-5 to -0.4204 ; MBE from -0.0003 to 0.1962 for the same slice thicknesses while that of solar dried sample the value of R2 ranged from 0.985 to $0.999 ; \chi 2$ ranged from 7.798 x10-7 to 5.306 x10-4; RMSE from 8.175 x10-6 to 0.01717 and MBE from 4.314 x105 to $6.490 \times 10-3$. The highest R2 and the lowest values for $\chi 2$, RMSE and MBE for the models were generally obtained from the Page model at a slice thickness of $0.5 \mathrm{~cm}$. Thus the model that best describes the drying of okro was Page model at slice thickness of $0.5 \mathrm{~cm}$ for all the drying temperatures/methods.

The established model was used to predict the moisture ratio of okro. The validation was done by trying to compare the predicted moisture ratio with the experimented as shown in Figures 1. Generally, there was good agreement between the experimental and predicted variables except for sample dried at a temperature of $50{ }^{\circ} \mathrm{C}$ which tend to deviate. These indicates that Page model could be used to predict the thin layer drying of okro using sun, solar and oven $\left(40,45\right.$ and $\left.50{ }^{\circ} \mathrm{C}\right)$ drying and at slice thickness of $0.5 \mathrm{~cm}$. This result agrees with the finding of Famurewa and Olumofin (2015) who stated that Page model was best describe the drying characteristic of okro dried at temperature of 40,50 and $60^{\circ} \mathrm{C}$ and at a particle size of $0.2,0.3$ and $0.4 \mathrm{~mm}$.

Table 2: Statistical Parameters for Selected Thin Layer Model on the Drying of Okro at Different Temperatures

\begin{tabular}{|l|l|l|l|l|l|l|}
\hline $\begin{array}{c}\text { Drying } \\
\text { Method }\end{array}$ & \multicolumn{1}{|c|}{ Model } & $\begin{array}{c}\text { Slice } \\
\text { Thickness(cm) }\end{array}$ & \multicolumn{1}{|c|}{$\mathbf{R}^{2}$} & \multicolumn{1}{c|}{ RMSE } & \multicolumn{1}{c|}{ MBE } \\
\hline & Newton & 0.5 & 0.992 & $6.26 \times 10^{-3}$ & $7.64 \times 10^{-2}$ & $-1.97 \times 10^{-2}$ \\
\hline Oven $40^{\circ} \mathrm{C}$ & & 1.5 & 0.879 & $1.83 \times 10^{-2}$ & $1.308 \times 10^{-1}$ & $-3.38 \times 10^{-2}$ \\
\hline & & 2.0 & 0.922 & $2.73 \times 10^{-3}$ & $5.04 \times 10^{-2}$ & $1.3 \times 10^{-2}$ \\
\hline & Page & 0.5 & 0.996 & $1.38 \times 10^{-2}$ & $1.14 \times 10^{-2}$ & $2.9308 \times 10^{-3}$ \\
\hline & & 1.5 & 0.995 & $9.41 \times 10^{-5}$ & $9.37 \times 10^{-3}$ & $2.4202 \times 10^{-3}$ \\
\hline & 2.0 & 0.994 & $5.38 \times 10^{-5}$ & $7.09 \times 10^{-3}$ & $-1.83 \times 10^{-3}$ \\
\hline & $\begin{array}{l}\text { Henderson } \\
\text { \& Pabis }\end{array}$ & 0.5 & 0.927 & $6.08 \times 10^{-2}$ & $2.382 \times 10^{-1}$ & $6.15 \times 10^{-2}$ \\
\hline & & 1.5 & 0.925 & $2.06 \times 10^{-5}$ & $4.383 \times 10^{-3}$ & $1.130 \times 10^{-3}$ \\
\hline & & 2.0 & 0.958 & $5.380 \times 10^{-5}$ & $7.088 \times 10^{-3}$ & $-1.830 \times 10^{-3}$ \\
\hline & Newton & 0.5 & 0.892 & $4.559 \times 10^{-3}$ & $6.52 \times 10^{-2}$ & $-1.68 \times 10^{-2}$ \\
\hline Oven $45^{\circ} \mathrm{C}$ & & 1.5 & 0.978 & $1.97 \times 10^{-2}$ & $1.84 \times 10^{-2}$ & $3.50 \times 10^{-2}$ \\
\hline & & 2.0 & 0.954 & $3.31 \times 10^{-2}$ & $1.1757 \times 10^{-2}$ & $-4.54 \times 10^{-2}$ \\
\hline & Page & 0.5 & 0.998 & $0.152 \times 10^{-8}$ & $0.213 \times 10^{-4}$ & $-3.7 \times 10^{-3}$ \\
\hline
\end{tabular}


DOI: 10.5281/zenodo.2636809

\begin{tabular}{|l|l|l|l|l|l|l|}
\hline & & 1.5 & 0.996 & $3.881 \times 10^{-7}$ & $6.018 \times 10^{-4}$ & $2.0 \times 10^{-4}$ \\
\hline & & 2.0 & 0.996 & $1.301 \times 10^{-4}$ & $4.702 \times 10^{-4}$ & $1.0 \times 10^{-2}$ \\
\hline & $\begin{array}{l}\text { Henderson } \\
\text { \& Pabis }\end{array}$ & 0.5 & 0.927 & $3.974 \times 10^{-4}$ & $1.92 \times 10^{-2}$ & $5.0 \times 10^{-3}$ \\
\hline & & 1.5 & 0.990 & $1.765 \times 10^{-2}$ & $1.283 \times 10^{-1}$ & $2.333 \times 10^{-1}$ \\
\hline & & 2.0 & 0.976 & $1.466 \times 10^{-8}$ & $1.170 \times 10^{-4}$ & $3.021 \times 10^{-5}$ \\
\hline & Newton & 0.5 & 0.986 & $2.374 \times 10^{-3}$ & $4.62 \times 10^{-2}$ & $1.46 \times 10^{-2}$ \\
\hline & & 1.5 & 0.989 & $3.090 \times 10^{-3}$ & $5.30 \times 10^{-2}$ & $-1.67 \times 10^{-2}$ \\
\hline & & 2.0 & 0.985 & $2.310 \times 10^{-3}$ & $4.80 \times 10^{-2}$ & $-1.52 \times 10^{-2}$ \\
\hline & Page $50^{\circ} \mathrm{C}$ & 0.5 & 0.999 & $2.265 \times 10^{-6}$ & $0.045 \times 10^{-4}$ & $1.43 \times 10^{-2}$ \\
\hline & & 1.5 & 0.989 & $2.557 \times 10^{-4}$ & $1.600 \times 10^{-2}$ & $5.1 \times 10^{-3}$ \\
\hline & & 2.0 & 0.985 & $7.100 \times 10^{-5}$ & $7.990 \times 10^{-3}$ & $2.5 \times 10^{-3}$ \\
\hline & $\begin{array}{l}\text { Henderson } \\
\text { \& Pabis }\end{array}$ & 0.5 & 0.988 & $2.250 \times 10^{-3}$ & $4.50 \times 10^{-2}$ & $1.42 \times 10^{-2}$ \\
\hline & & 1.5 & 0.989 & $7.336 \times 10^{-6}$ & $2.570 \times 10^{-3}$ & $8.0 \times 10^{-4}$ \\
\hline & & 2.0 & 0.985 & $1.690 \times 10^{-5}$ & $1.235 \times 10^{-3}$ & $4.0 \times 10^{-4}$ \\
\hline
\end{tabular}

Table 3: Statistical Parameters for Selected Thin Layer Model on the Drying of Okro using Sun

\begin{tabular}{|c|c|c|c|c|c|c|}
\hline $\begin{array}{l}\text { Drying } \\
\text { Method }\end{array}$ & Model & $\begin{array}{c}\text { Slice } \\
\text { thickness }\end{array}$ & $\overline{\mathbf{R}^{2}}$ & $\mathbf{X}^{2}$ & RMSE & MBE \\
\hline & Newton & 0.5 & 0.961 & $1.356 \times 10^{-5}$ & $3.490 \times 10^{-4}$ & $-1.1 \times 10^{-2}$ \\
\hline \multirow[t]{9}{*}{ Sun } & & 1.5 & 0.997 & $1.001 \times 10^{-6}$ & $9.490 \times 10^{-4}$ & $-3 \times 10^{-4}$ \\
\hline & & 2.0 & 0.967 & $3.835 \times 10^{-4}$ & $1.85 \times 10^{-2}$ & $-5.880 \times 10^{-2}$ \\
\hline & Page & 0.5 & 0.999 & $8.327 \times 10^{-7}$ & $8.656 \times 10^{-5}$ & $-2.7 \times 10^{-3}$ \\
\hline & & 1.5 & 0.998 & $1.301 \times 10^{-6}$ & $1.082 \times 10^{-3}$ & $-3.4 \times 10^{-3}$ \\
\hline & & 2.0 & 0.996 & $1.750 \times 10^{-5}$ & $3.997 \times 10^{-3}$ & $1.3 \times 10^{-3}$ \\
\hline & $\begin{array}{l}\text { Henderson \& } \\
\text { Pabis }\end{array}$ & 0.5 & 0.970 & $1.162 \times 10^{-3}$ & $3.23 \times 10^{-2}$ & $1.02 \times 10^{-2}$ \\
\hline & & 1.5 & 0.998 & $3.660 \times 10^{-6}$ & $1.815 \times 10^{-3}$ & $6.0 \times 10^{-4}$ \\
\hline & & 2.0 & 0.998 & $1.330 \times 10^{-1}$ & $4.204 \times 10^{-1}$ & $1.960 \times 10^{-1}$ \\
\hline & Newton & 0.5 & 0.986 & $1.500 \times 10^{-4}$ & $1.14 \times 10^{-2}$ & $-4.314 \times 10^{-3}$ \\
\hline \multirow[t]{8}{*}{ Solar } & & 1.5 & 0.989 & $9.118 \times 10^{-6}$ & $8.84 \times 10^{-6}$ & $3.314 \times 10^{-6}$ \\
\hline & & 2.0 & 0.985 & $5.306 \times 10^{-4}$ & $1.404 \times 10^{-3}$ & $2.299 \times 10^{-6}$ \\
\hline & Page & 0.5 & 0.999 & $7.798 \times 10^{-7}$ & $8.175 \times 10^{-6}$ & $-3.089 \times 10^{-4}$ \\
\hline & & 1.5 & 0.989 & $1.045 \times 10^{-6}$ & $2.993 \times 10^{-4}$ & $1.131 \times 10^{-4}$ \\
\hline & & 2.0 & 0.985 & $3.968 \times 10^{-6}$ & $1.844 \times 10^{-4}$ & $6.971 \times 10^{-5}$ \\
\hline & $\begin{array}{l}\text { Henderson \& } \\
\text { Pabis }\end{array}$ & 0.5 & 0.988 & $3.439 \times 10^{-4}$ & $1.72 \times 10^{-2}$ & $6.490 \times 10^{-3}$ \\
\hline & & 1.5 & 0.989 & $5.108 \times 10^{-5}$ & $1.351 \times 10^{-4}$ & $5.108 \times 10^{-5}$ \\
\hline & & 2.0 & 0.985 & $1.359 \times 10^{-4}$ & $3.595 \times 10^{-4}$ & $1.508 \times 10^{-7}$ \\
\hline
\end{tabular}


DOI: $10.5281 /$ zenodo.2636809
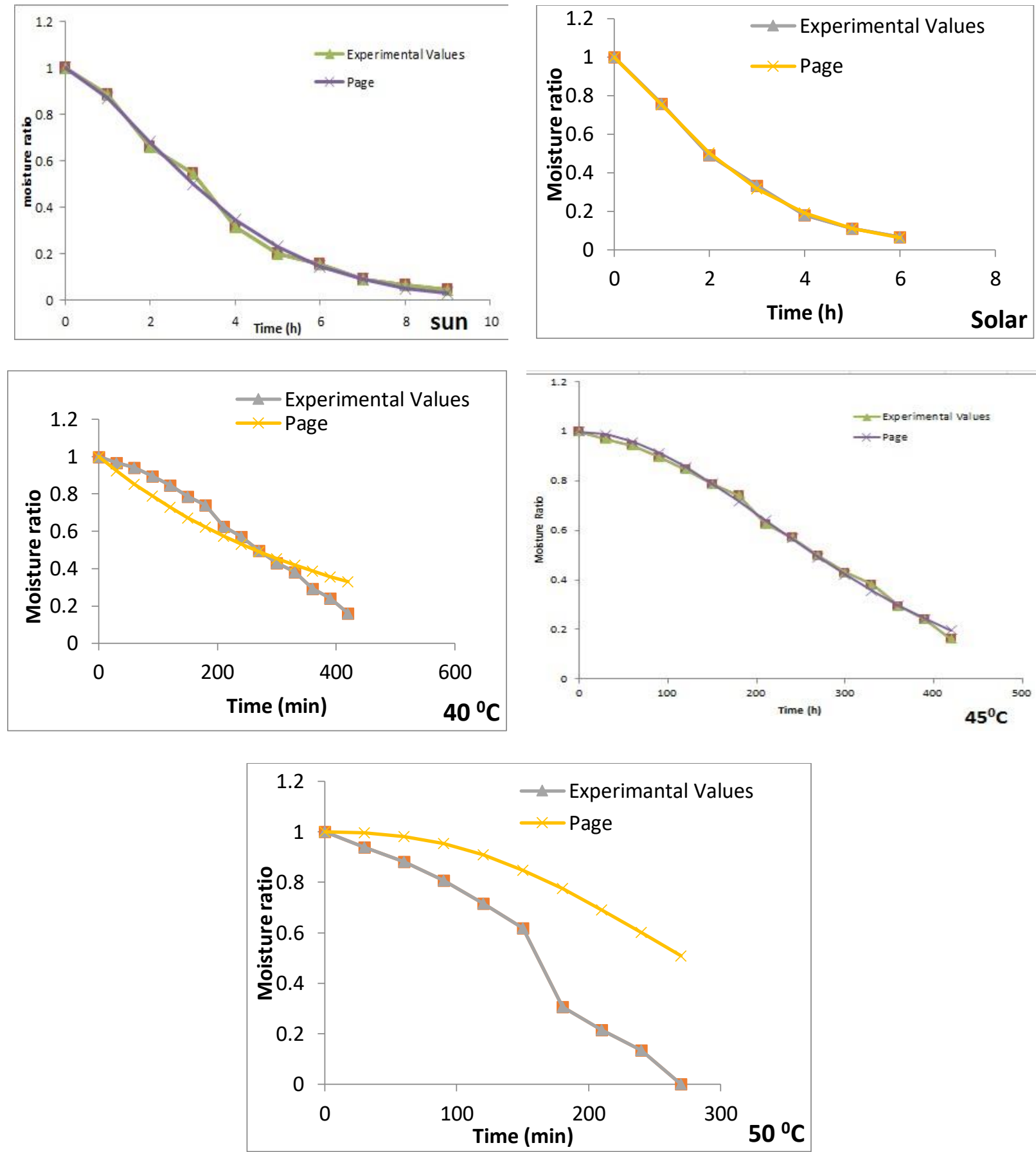

Figure 1: Comparison of experimental and predicted moisture ratio against drying time for sun, solar and oven $\left(40,45\right.$ and $\left.50{ }^{\circ} \mathrm{C}\right)$ drying of okro

\section{Conclusion}

Drying kinetics of okro samples (Abelmoschus esculentus L.) were examined by introducing three empirical thin layer drying models (Newton, Page and Henderson and Pabis). The models were fitted into experimental data obtained from oven drying $\left(40,45\right.$ and $\left.50{ }^{\circ} \mathrm{C}\right)$, sun drying and solar 
drying. From the result obtained, Page model was the one that best fit and perfectly describes the thin layer drying characteristic of okro.

\section{References}

[1] AOAC 2005. Official method of analysis. Association of Official Analytical Chemists, Maryland, USA. 18th Edition.

[2] Darvishi, H., Farhang, A. and Hazbavi, E. 2012. Mathematical modelling of thin-layer drying of shrimp. Global Journal of Science Frontier Research, 12(3):83 - 89.

[3] Famurewa, J.A.V. and Olumofin, K.M. 2015. Drying kinetics and influence on the chemical characteristics of hydrated okro (Abelmoschus esculentus) using cabinet dryer. Journal of Engineering and Technology, 3: 7 - 19.

[4] Gemede, H. F., Ratta, N., Haki, G. D. and Woldegiorgis, A. Z. 2014. Nutritional quality and health benefits of okro (Abelmoschus esculentus). Journal of Medical Research Interdisciplinary, 14: 22 $-25$.

[5] Krutman, A. 1981. Development of alternative dehydration methods for okro. Dissertation abstracts international. Science Journal, 42 (2): 551.

[6] Liu, Q. and Bakker-Arkema, F. W. 1997. Stochastic modeling of grain drying, Part 2. Model Development. Journal of Agricultural Engineering Research, 66 (4): 275 - 280.

[7] Mana, L.V., Orikasab, T., Murramatsuc, Y. and Tagawaa, A. 2012. Impact of microwave drying on the quality of okro fruit. Journal of Food Process and Technology, 5(6): 23 - 45.

[8] Maskan, M. 2002. Effect of processing on hydration kinetics of three wheat products of the same variety. Journal of Food Engineering, 52(4):337 -341.

[9] Menges, H.O. and Ertekin, C. 2006. Mathematical modeling of thin-layer drying of golden apples. Journal of Food Engineering, 77: $119-125$.

[10] Mohamed, L. A., Kouhila M., Jamali A., Lahsasni S., Kechaou N. and Mahrouz, M. 2005. Single layer solar drying behaviour of Citrus aurantium leaves under forced convection. Energy Conversion and Management, 46:1473-1483.

[11] Pandey, S. K., Diwan, S. and Soni, R. 2015. Review of mathematical modelling of thin layer drying process. International Journal of Current Engineering and Scientific Research, 2:96 - 107.

[12] Taheri-Garav, A. S. R. and Alireza, K. 2011. Study on effective moisture diffusivity, activation energy and mathematical modeling of thin layer drying kinetics of bell pepper. Australian Journal of Crop Science, 5(1): $53-62$.

[13] Tuned-Akintunde, T. Y., Afolabi, T. J. and Akintunde, B. O. 2005. Influence of drying methods on drying of bell pepper (Capsicum annuum). Journal of Food Engineering, 79: 1460 - 1466.

[14] Tunde-Akintunde, T. Y. and Ajala, A. S. 2010. Air drying characteristics of chilli pepper. International Journal of Food Engineering, 68: 23 - 32.

[15] Wankhade, P. K. and Saplid, V. S. 2012. Drying characteristics of okro slices using different drying method by comparative evaluation. Journal of Engineering and Computer Science, 2: 40 - 45.

[16] Zhang, Q. and Litchfield, J. B. 1991. Optimization of intermittent corn drying in a laboratory scale thin layer dryer. Journal of Engineering and Technology, 26: 70 - 73.

\footnotetext{
*Corresponding author.

E-mail address: olajiresola@ yahoo.com
} 